\title{
Allelopathic Potential of Wheat on Sourgrass Resistant to Glyphosate
}

\author{
Marcio Akira Ito ${ }^{1}$, Germani Concenço ${ }^{1}$, Rodolpho Freire Marques $^{2}$, \\ Sabrina Alves dos Santos ${ }^{3}$, Maxwell Eliezer dos Santos Alves ${ }^{4}$, Waggner Gomes Palharini4, \\ Thais Stradioto Melo ${ }^{4}$, Laryssa Barbosa Xavier Silva ${ }^{4}$, Larissa Tagara Linhares ${ }^{4}$, \\ Samara Emerim Concenço 5 \\ ${ }^{1}$ Sustainable Cropping Systems, Embrapa Western Agriculture, Dourados, Brazil \\ ${ }^{2}$ Federal University of Grande Dourados, UFGD, Dourados, Brazil \\ ${ }^{3}$ University of Grande Dourados, UNIGRAN, Dourados, Brazil \\ ${ }^{4}$ University Anhanguera, Dourados, Brazil \\ ${ }^{5}$ Federal Institute of Santa Catarina, Santa Rosa do Sul, Brazil \\ Email: marcio.ito@embrapa.br
}

Received 11 February 2015; accepted 10 April 2015; published 13 April 2015

Copyright $@ 2015$ by authors and Scientific Research Publishing Inc.

This work is licensed under the Creative Commons Attribution International License (CC BY).

http://creativecommons.org/licenses/by/4.0/

\section{cC) (7) Open Access}

\begin{abstract}
We aimed with this study to assay the allelopathic potential of wheat genotypes in inhibiting germination and initial growth of sourgrass (Digitaria insularis) resistant to the herbicide glyphosate. Two experiments were installed under greenhouse conditions: the first one aimed to assay the potential of wheat genotypes in inhibiting emergence and initial growth of two test plants, and the second aimed to evaluate the potential of those wheat genotypes which performed better at the first experiment, inhibiting the emergence and initial growth of sourgrass biotypes resistant to the herbicide glyphosate. Five doses of aqueous cool-extracted extract from 32 wheat genotypes were applied to tomato and cucumber (Experiment 1) aiming to identify the ones with higher inhibitory effect. The five most inhibitory wheat genotypes were selected for Experiment 2, where the same doses of extract were applied on sourgrass. For both experiments, shoot fresh and dry mass, as well as water content, were assessed. Sourgrass germination is affected by wheat extracts, but initial seedling growth seems not to be affected; wheat genotypes differ in terms of their allelopathic potential in inhibiting sourgrass germination; wheat presents little inhibitory effect on sourgrass.
\end{abstract}

\section{Keywords}

Triticum aestivum, Digitaria insularis, Herbicide Resistance, Soybean 


\section{Introduction}

Recent genetically modified organism (GMO) technologies have aimed to employ herbicide resistance to soybean cultivars, and have drastically reduced infestation of weed species in most fields with such technologies. However, lack of government regulation and farmers' mismanagement of such technologies led to selection of weed species tolerant or resistant to herbicides applied with these technologies [1]. The glyphosate-tolerant soybean was widely used in Brazil, and currently Conyza bonariensis (hairy fleabane), C. canadensis (horseweed), C. sumatrensis (sumatran fleabane), Digitaria insularis (sourgrass), and Lolium multiflorum (italian ryegrass) are resistant to glyphosate in Brazil, due to its extensive use in Roundup Ready ${ }^{\circledR}$ soybean [2]. Species of Conyza (fleabane, horseweed) and sourgrass are considered the most troublesome weeds in Brazilian Roundup Ready ${ }^{\circledR}$ soybean cropping systems [3].

One of the main management practices which contribute to the reduction in weeds infestation is the continuous maintenance of straw on soil [4] [5], which among other impacts, limits weeds access to light. In addition, some plant species produce chemicals which are accumulated in soil, inhibiting germination and/or growth of other plant species. This phenomenon is called allelopathy [6].

It is widely known in Brazilian agriculture the allelopathic effect of wheat on hairy fleanabe, horseweed and sumatran fleabane [7] [8]. Paula et al. [7] reported that, at the pre-planting of soybeans, hairy fleabane infestation was reduced from 172 plants $\cdot \mathrm{m}^{-2}$ to 43 plants $\cdot \mathrm{m}^{-2}$ only due to wheat cultivation in the preceding winter. Furthermore, infestation was reduced to 15 plants $\mathrm{m}^{-2}$ if iodosulfuron-methyl was used in wheat. Lamego et al. [8] highlight that in addition to a winter species efficient in reducing Conyza establishment, a good burndown prior to planting soybean is essential to reduce problems post-emergence.

We took this effect of wheat on Conyza spp. as a background for further studies. Although the effect of wheat on Conyza spp. is well known and widely used by farmers from Conyza-infested regions, there is no information about its effects in sourgrass, whose infestation is becoming widespread [9]. Considering our observations in soybean-wheat fields regarding weed infestation and population change, we hypothesize that wheat presents little to no efficiency in suppressing sourgrass compared with the level that it affects species of Conyza. Thus, we aimed with this study to assay the allelopathic potential of wheat genotypes in inhibiting germination and initial growth of sourgrass (Digitaria insularis) resistant to the herbicide glyphosate.

\section{Materials and Methods}

Two experiments were installed under greenhouse conditions. The first experiment aimed to screen the potential of wheat genotypes in inhibiting emergence and initial growth of test plants, and the second to assess the potential of those wheat lineages which performed better at the first experiment, in inhibiting the emergence and initial growth of sourgrass (Digitaria insularis) biotypes resistant to the herbicide glyphosate [10].

\section{Experiment 1}

Thirty two cultivars and lineages of wheat with distinct genetic origins from the breeding program of Embrapa Wheat (Passo Fundo-RS) at the stage of pre-selection for being launched as Cultivars were used at the first study. The study was installed under greenhouse in completely randomized design with factorial scheme $32 \times 6$ $\times 2$, with five replications. Factor A comprised the 32 wheat lineages (numbered $01-32$ ), factor B six doses of previously prepared wheat extract, and factor $\mathrm{C}$ the two plant species used as indicators of inhibiting ability.

Experimental plots were composed by plastic pots with capacity for $2 \mathrm{~L}$ of soil, which were filled with $1.6 \mathrm{~kg}$ of Oxisol with $60 \%$ clay and $2.6 \%$ organic matter, where six seeds of tomato or cucumber, according to the treatment, were planted $1 \mathrm{~cm}$ depth.

Wheat plants were collected at heading stage (10.1), and extracts were prepared by taking $250 \mathrm{~g}$ of leaves from each wheat genotype, which were put into an industrial mixer grinder plus one liter of distilled cool water for processing for three minutes at full power. The mixture was passed through a fine-mesh strainer for residue removal, and $750 \mathrm{~mL}$ of the resulting solution was divided into six doses: 0, 50, 100, 150, 200 and $250 \mathrm{~mL}$. These doses were completed to $500 \mathrm{~mL}$ with distilled cool water being kept into refrigerator at $2^{\circ} \mathrm{C} \pm 0.5^{\circ} \mathrm{C}$ until all samples were processed.

Doses of extracts were applied just once, on plots planted at the same day with tomato or cucumber, according to the treatment. Application was accomplished by using the extract doses obtained in laboratory, completed to $500 \mathrm{~mL}$ with distilled water, being applied on soil surface by using a watering can, and for 14 days from planting and extract application (DAA), plots were kept wet with distilled water and plant emergence was counted from 2 
to 14 DAA. Emergence speed, fresh and dry mass of cucumber and tomato plants were also evaluated and considered to infer about the differential ability of each wheat genotype in inhibiting plant emergence and vigor. Due to the huge amount of data, however, for experiment 1 only emergence speed is presented for all genotypes; plant height, fresh and dry mass were considered for selecting genotypes for the second experiment, but were not shown.

Data residuals (errors) were subjected to analysis of normality and homogeneity of variances, respectively by Shapiro-Wilk and Bartlett tests, and transformed when needed, being submitted to analysis of variance by the F-test at 5\% probability. Emergence speed curve was presented based on moving averages. All analyses were run and graphs drawn into the statistical environment " $R$ " [11].

\section{Experiment 2}

For the second experiment, the five wheat genotypes most efficient in inhibiting the indicator species (tomato and cucumber) were chosen. The study was also conducted under greenhouse, in completely randomized design under factorial scheme $5 \times 6$, with same plot size, replication number, soil amount and extract processing method used in experiment 1. Factor A represented the five wheat genotypes previously selected, and factor B the doses of wheat extract.

Due to the small size of sourgrass seeds, seed samples were weighted, being exactly $1.45 \mathrm{~g}$ of seeds planted per plot at $0.7-1 \mathrm{~cm}$ depth. Extract samples were then applied on plots according to the previously described, at the same day of planting, and plant emergence was counted for 20 DAA. At the end of this period, height of 10 plants per plot was evaluated and plants were cut at soil level for fresh and dry mass determination, being also obtained the water content (WC) by the following formula:

$$
\mathrm{WC}=\frac{(\mathrm{SFW}-\mathrm{SDW})}{\mathrm{SFW}}
$$

where $\mathrm{WC}=$ water content $(\%)$; SFW $=$ shoot fresh weight; SDW = shoot dry weight.

Data residuals (errors) were subjected to analysis of normality and homogeneity of variances respectively by Shapiro-Wilk and Bartlett tests, and transformed when needed, being submitted to analysis of variance by the F-test at 5\% probability. When treatment effect was significant, regression analysis was used for quantitative data. All analyses were run into the statistical environment " $R$ " [11].

\section{Results and Discussion}

\section{Experiment 1}

Cucumber [12] and tomato [13] are known to be sensitive to a range of compounds with allelopathic activity, being thus widely used as test plants in allelopathic bioassays. Ells and McSay [12] reports that the inhibitory effect of plants on cucumber may be assessed either by planting its seeds on the medium treated with the compound to be studied or by transplanting pre-germinated cucumber seeds to the medium. We opted for planting seeds on the medium that would receive the treatment. Shayghan and Sedghi [14] also report that bioassays with indicative plants as tomatoes are essential to characterize the potential of a given species in inhibiting growth of weed species.

Regarding the effect of the distinct genotypes on cucumber and tomato (Figure 1), there was significant difference among them in the emergence behavior of cucumber compared to tomato; for cucumber the initial emergence curve was similar for most treatments, but in contrast, the final percentage of emergence was distinct; from the six seeds planted in each plot, from 1 to 5 were emerged at 14 DAA depending on wheat genotype. Cucumber helped to discriminate genotypes according to the final percentage of emergence in detriment of emergence curve behavior (Figure 1).

For tomato an opposite behavior is observed; while the final percentage of emergence varies from 4 to 6 plants per plot, the emergence curves had distinct behavior. For wheat genotype \# 06, for example, 4 plants (83\%) were emerged two days after planting while for lineage \# 22 this number of plants was found emerged only 14 DAA (Figure 1).

Wu et al. [15] report that the allelopathic effect of wheat on ryegrass (Lolium rigidum) was positively correlated with total phenolic acids content, and Lam et al. [16] report that hydroxamic acids are also involved in wheat allelopathic ability. Thus, although not possible in this study, the assessment of phenolic and hydroxamic contents would help selecting those genotypes with superior contents of allelopathically effective compounds in 
CUCUMBER
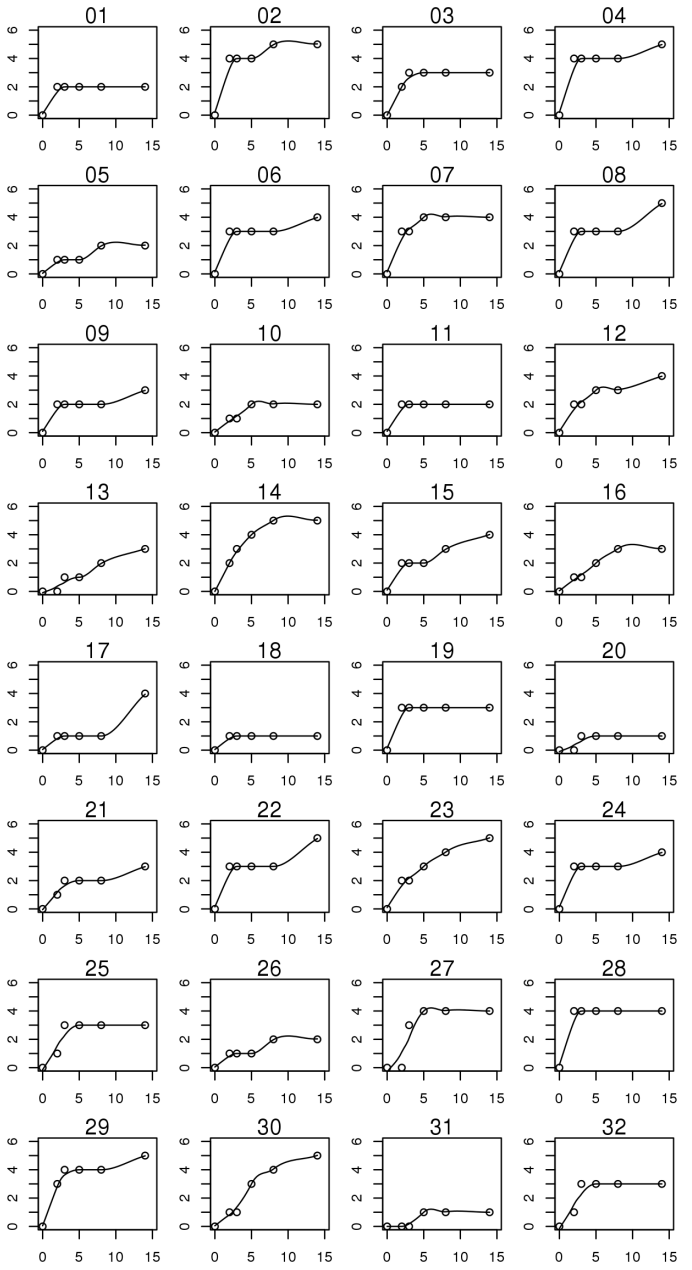

Figure 1. Emergence curves (y axis) of cucumber and tomato as a function of wheat genotype (1 to 32 ) and days after planting ( $\mathrm{x}$ axis), following application of the full dose of the extract $\left(250 \mathrm{~mL} \mathrm{plot}^{-1}\right)$. Emergence speed tendency is presented as moving averages. Embrapa Agropecuária Oeste, Dourados, MS, Brazil, 2014.

breeding programs aiming to a possible improvement for cultural weed inhibition in cropping systems [17]. Genotypes \# 03, 05, 09, 20 and 26 were the ones which promoted most pronounced inhibitory effect for most of the variables (Figure 1), being thus selected for the second experiment.

\section{Experiment 2}

Both genotype and dose of extract presented distinct effects on sourgrass emergence (Figure 2). Genotype \# 03 did not affect at all plant emergence, being all doses of extract similar to the check; plants started emerging 5 DAA, being the emergence stabilized by 18 DAA with about 15 plants per plot (Figure 2). This genotype corresponds to the cv. BRS Guamirim, commercially available for farmers. We hypothesize that areas planted with this wheat cultivar may present high sourgrass infestation supposing this species is present at the soil seed bank.

Genotype \# 05 affected differently sourgrass emergence as wheat extract dose was increased (Figure 2). From zero to $150 \mathrm{~mL} \mathrm{plot}^{-1}$, no differences were observed in sourgrass emergence; when 200 or $250 \mathrm{~mL}$ were applied per plot, emergence speed of sourgrass was reduced in about 56\% 15 DAA, and in 47\% 18 DAA. Genotype \# 05 corresponds to the commercially available cultivar BRS 276 , which similarly to genotype \# 03 is a short-cycle variety (54 - 68 days from emergence to heading) widely used in Southern Brazil [18].

Genotypes \# 09 and \# 20 were similar in behavior, where only the smaller extract dose $\left(50 \mathrm{~mL} \mathrm{plot}^{-1}\right)$ was similar to the check, being the other doses similar among them. Compared to the first group, doses from $100 \mathrm{~mL}$ plot $^{-1}$ on, for both genotypes, reduced in about $33 \%$ the final sourgrass emergence as well as emergence speed, 

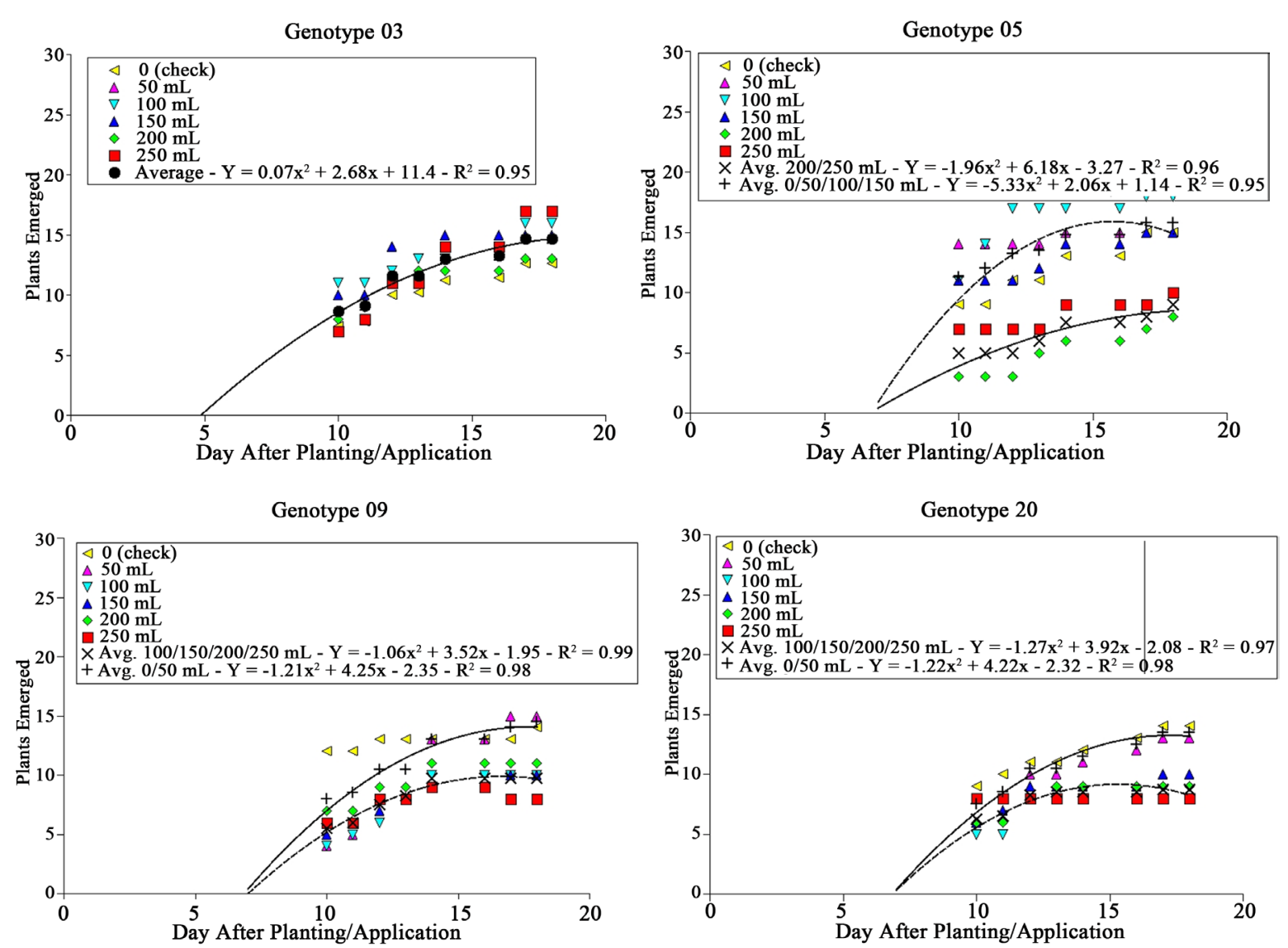

Genotype 26

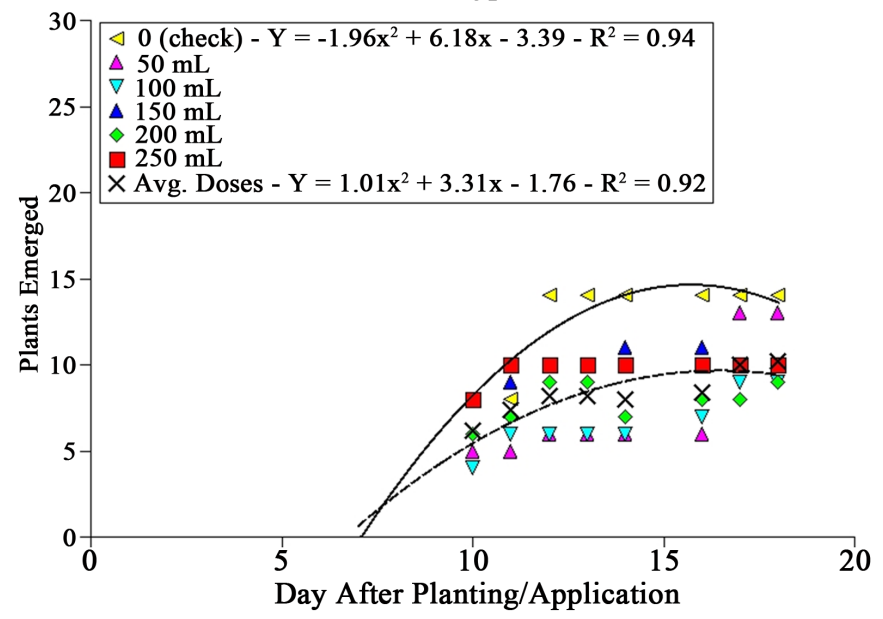

Figure 2. Sourgrass emergence curves as a function of wheat genotype, dose of extract and days after planting/application, under controlled environment. Embrapa Agropecuária Oeste, Dourados, MS, 2014.

which can be inferred by comparing the growing divergence between curves of both groups under the same genotype as days passed (Figure 2). Genotypes \# 09 and \# 20 corresponds respectively to lineages IPF 100010 and PF 101009, which are not yet commercially available.

Genotype \# 26, which corresponds to lineage PF 101014 also not yet commercially available, affected sourgrass emergence at any dose compared to the check (Figure 2). From 11 DAA, emergence under application of any dose of extract reached 10 plants per plot, while at the check about 15 plants per plot were observed. 
Genotypes \# 05 and \# 26 were the most consistent ones regarding suppressive effect on sourgrass emergence, since for the former larger differences were observed between the check and higher doses tested, and the latter was efficient at any dose of extract compared to check (Figure 2). In general terms, it can be noted that wheat seems not to be effective in inhibiting sourgrass emergence since the doses tested $-0,50,100,150,200$ and 250 $\mathrm{mL}$ plot $^{-1}$ correspond roughly to $0,7.5,15,22.5$ and $30 \mathrm{t}^{\mathrm{h}} \mathrm{ha}^{-1}$ of dry mass, considering all regarded dilutions and transformations used at Material and Methods. The amount of straw left on soil after wheat cultivation, under field conditions, traditionally averages about $5 \mathrm{t} \cdot \mathrm{ha}^{-1}[19]$.

The fresh and dry mass, as well as water content of sourgrass seedlings 20 DAA, is shown in Figure 3. Although graphically one is impelled to recognize differences among genotypes due to the very strict scale range presented at $\mathrm{Y}$-axis, analysis of variance by the F-test showed no difference among genotypes for fresh and dry mass and water content; there was difference, however, for dose of extract.

This significance for extract leads to an uncommon result; wheat extracts applied on soil previously planted with sourgrass, although with some inhibitory effect on germination speed and total germination (Figure 2), seemed to stimulate sourgrass seedling growth after emergence as dose was increased (Figure 3). This stimulation is not related to differential soil moisture since all plots received the same amount of water at every irrigation, even at planting where check plots were irrigated with $500 \mathrm{~mL}$ of distilled water while the other treatments received the same volume of solution (extract concentration varied according to Material \& Methods).

This behavior should be confirmed in a further study, but results were consistent both statistically as well as visually-taller and most vigorous sourgrass seedlings were reported by all evaluators, for most genotypes, as extract dose was increased. We have four hypotheses: 1) wheat suppression on sourgrass is specific for germina-
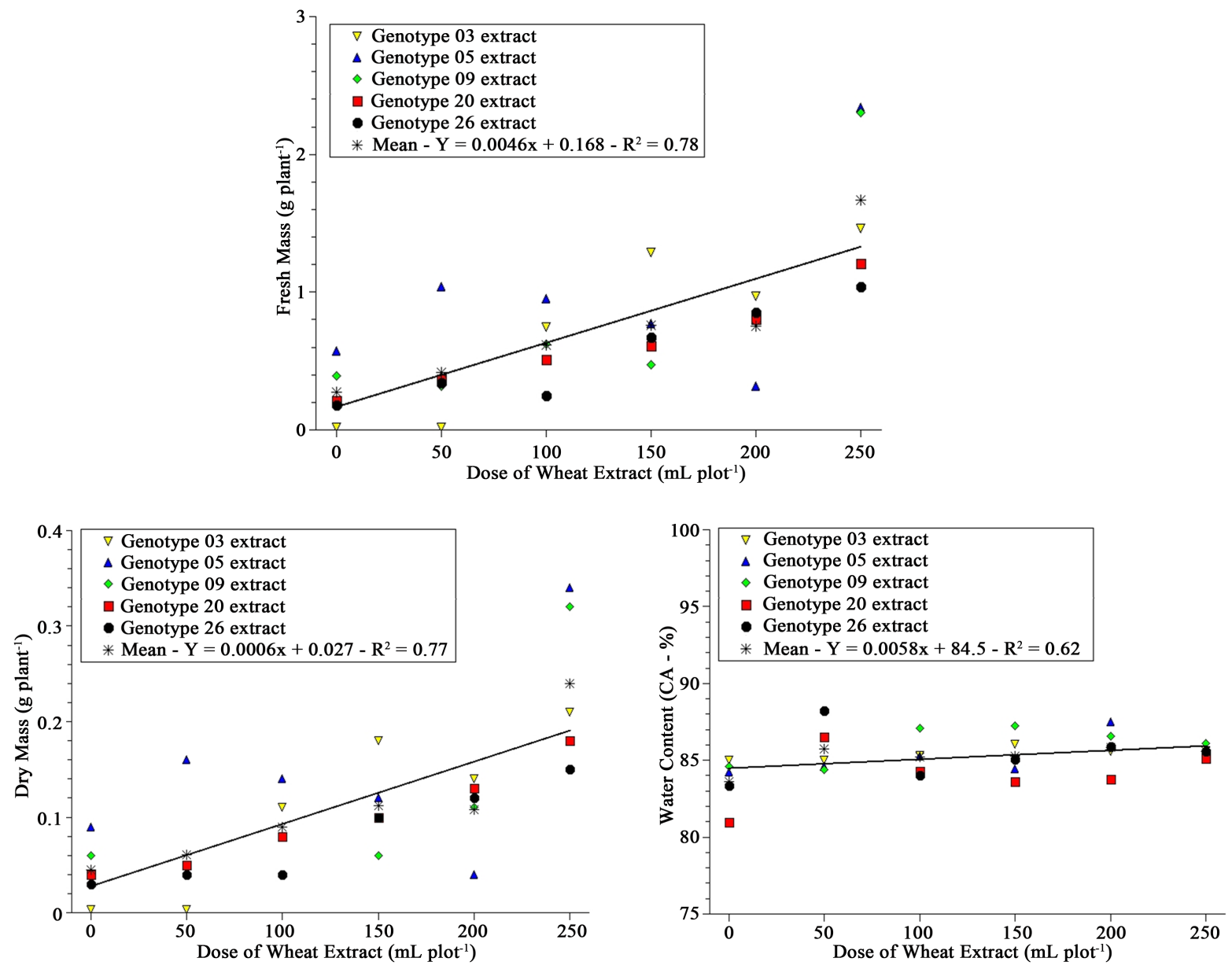

Figure 3. Fresh and dry mass and water content of sourgrass plants 20 days after emergence as a function of wheat genotype and dose of extract under controlled environment. Embrapa Agropecuária Oeste, Dourados, MS, 2012. 
tion; 2) wheat/sourgrass type of interference, positive, negative or neutral, is dependent upon growth and development stages; 3 ) competitive aspects not documented may be affecting our results; 4) a process of allelomediation - changes to the physical or biological environment caused by wheat which in turn favors sourgrass - may be occurring. There are currently no scientific reports about allelopathic or allelomediated effects of sourgrass on other plant species [20], but the opposite may be true. This discussion is partially out of the scope of this study, but this behavior was registered and will be further investigated.

The use of allelopathy as a less impacting weed management tool is gathering attention from the public due to its ecological and environmental appeal, but results from controlled environment studies often fail to correlate to field results, where the suppressive ability is often lower than the observed under greenhouse or laboratory trials [21]. Physical, chemical and biological soil processes may result in detoxification or inactivation of compounds with allelopathic activity, which would pose serious limitations to the results, mainly for those experiments carried out in absence of soil.

Wheat is recognized as potential inhibitor of several weed species, among them Conyza spp. [7] [8], several other weeds and crops as rice, barley, rye and cotton, among others [16]. Based on our results we believe wheat unfortunately has little effect on sourgrass; it can reduce plant emergence at some extent, but plants which are able to germinate apparently present most pronounced initial growth compared to those grown in absence of wheat. Thus, in the cropping systems of Central Brazil, other crops should be tested aiming to help reducing sourgrass biotypes resistant to the herbicide glyphosate, just as wheat is suppressive for Conyza-infested areas.

\section{Conclusion}

Sourgrass (Digitaria insularis) germination is affected by wheat extracts, but wheat genotypes differ in terms of their ability in inhibiting sourgrass germination; initial seedling growth of sourgrass seems not to be affected by wheat extracts; overall, wheat seems to present little inhibitory effect on sourgrass.

\section{References}

[1] Trezzi, M.M., Nunes, A.L. and Portes, E.S. (2007) Manejo de plantas daninhas através de métodos alternativos ao método químico. In: Martin, T.N. and Montagner, M.M., Ed., Sistemas de produção agropecuária, UTFPR, Dois Vizinhos, 26-44.

[2] Heap, I. (2014) The International Survey of Herbicide Resistant Weeds. [S.1.]: Weed Science. http://www.weedscience.org/In.asp

[3] Gazziero, D.P., Adegas, F.S. and Voll, E. (2008) Glifosate e a soja transgênica. http://www.cnpso.embrapa.br/download/cirtec/circtec60.pdf

[4] Meschede, D.K., Ferreira, A.B. and Ribeiro Junior, C.C. (2007) Avaliação de diferentes coberturas na supressão de plantas daninhas no Cerrado. Planta Daninha, 25, 465-471. http://dx.doi.org/10.1590/S0100-83582007000300005

[5] Gomes Junior, F.G. and Christoffoleti, P.J. (2008) Biologia e manejo de plantas daninhas em áreas de plantio direto. Planta Daninha, 26, 789-798. http://dx.doi.org/10.1590/S0100-83582008000400010

[6] Inderjit and Mallik, A.U. (2002) Chemical Ecology of Plants: Allelopathy in Aquatic and Terrestrial Ecosystems. Springer, Basel.

[7] Paula, J.M., Vargas, L., Agostinetto, D. and Nohatto, M.A. (2011) Manejo de Conyza bonariensis resistente ao herbicida glyphosate. Planta Daninha, 29, 217-227. http://dx.doi.org/10.1590/S0100-83582011000100024

[8] Lamego, F.P., Kaspary, T.E., Ruchel, Q., Gallon, M., Basso, C.J. and Santi, A.L. (2013) Manejo de Conyza bonariensis resistente ao glyphosate: Coberturas de inverno e herbicidas em pré-semeadura da soja. Planta Daninha, 31, 433-442. http://dx.doi.org/10.1590/S0100-83582013000200022

[9] Correia, N.M., Leite, G.J. and Garcia, L.D. (2010) Resposta de diferentes populações de Digitaria insularis ao herbicida glyphosate. Planta Daninha, 28,769-776. http://dx.doi.org/10.1590/S0100-83582010000400009

[10] Alves, M.E.S., Palharini, W.G., Santos, S.A., Marschall, I.R., Marques, R.F. and Concenço, G. (2014) Distribuição da resistência de Digitaria insularis ao herbicida glyphosate no Mato Grosso do Sul. In: Jornada de iniciação a pesquisa da Embrapa, 3, 2014, Dourados. Resumos... Dourados: Embrapa CPAO. CD-ROM.

[11] R Core Team (2013) R: A Language and Environment for Statistical Computing. R Foundation for Statistical Computing, Vienna. http://www.R-project.org/

[12] Ells, J.E. and Mcsay, A.E. (1991) Allelopathic Effects of Alfalfa Plant Residues on Emergence and Growth of Cucumber Seedlings. HortScience, 26, 368-370. 
[13] Qin, C., Nagai, M., Hagins, W. and Hobbs, R. (2011) The Allelopathic Effects of Juglone Containing Nuts. The Journal of Experimental Secondary Science, 1. www.jes2s.com/pdfs/qin article.pdf

[14] Shaygham, S. and Sedghi, S. (2013) Study of the Effects on the Germination of Weed. Journal of Biology and Today's World, 2, 284-288.

[15] Wu, H., Pratley, J.E., Lemerle, D., Haig, T. and Verbeek, B. (1998) Differential Allelopathic Potential among Wheat Accessions to Annual Ryegrass. Proceedings of the 9th Australian Agronomy Conference, Wagga Wagga, 20-23 July 1998, 567-571.

[16] Lam, Y., Sze, C., Tong, Y., Ng, T., Tang, S., Ho, J., Xiang, Q., Lin, X. and Zhang, Y. (2012) Research on the Allelopathic Potential of Wheat. Agricultural Sciences, 3, 979-985. http://dx.doi.org/10.4236/as.2012.38119

[17] Albuquerque, M.B., Santos, R.C., Lima, L.M., Melo Filho, P.A., Nogueira, R.J.M.C., Camara, C.A.G. and Ramos, A.R. (2011) Allelopathy, an Alternative Tool to Improve Cropping Systems. A Review. Agronomy for Sustainable Development, 31, 379-395. http://dx.doi.org/10.1051/agro/2010031

[18] Cunha, G.R. (2009) Oficina Sobre Trigo No Brasil. Embrapa Trigo, Passo Fundo.

[19] Hernani, L.C. and Endres, V.C. (1990) Sistemas de produção e cobertura do solo para implantação do plantio direto. In: $6^{\circ}$ Reunião da Comissão Centro-Sul-Brasileira de Pesquisa de Trigo 22-26, Campinas. Anais...Campinas.

[20] Carvalho, L.B. (2011) Interferência de Digitaria insularis em Coffea arabica e Respostas destas Espécies ao Glyphosate. Ph.D. Thesis, Faculdade de Ciências Agrárias e Veterinárias, Jaboticabal.

[21] Inderjit and Weston, L.A. (2000) Are Laboratory Bioassays for Allelopathy Suitable for Prediction of Field Responses? Journal of Chemical Ecology, 26, 2111-2118. http://dx.doi.org/10.1023/A:1005516431969 